\title{
Municipal Waste Landfill Site Selection Model for Bahrain
}

\author{
Mariam Aamer Khalil* and Saad MA Suliman
}

Department of Mechanical Engineering, College of Engineering, University of Bahrain, Bahrain

\begin{abstract}
The municipal solid waste landfill in Bahrain (Askar landfill) reached its end use capacity by 2016; however it's still operating and receiving municipal wastes. This research aims to find out an alternative site for the existing landfill to be used during the current period and for near future. Five landfill alternatives located next to Askar, and eleven decision criteria have been proposed. The study applies two analytical approaches to establish the best landfill. The adopted approaches are Fuzzy Set analysis and Analytical Hierarchal Process analysis; both approaches are based on multi-criteria decision. The results for both methodologies are almost the same as the ranking of the five alternatives for both methodologies are similar with slight difference in landfill positions 3 and 4 , where the best alternative is found to be landfill (3), which is located below the existing landfill at Askar.
\end{abstract}

Keywords: Landfill site; Municipal solid waste; Multi-criteria analysis; Fuzzy set analysis; Analytical hierarchal process

\section{Introduction}

Municipal Solid Waste (MSW) in the Kingdom of Bahrain is being a priority issue that needs sustainable solution. Most of the MSW is collected and transported from various locations in the country and is being disposed at the Askar Municipal Landfill Site, which is operational since 1987. Askar Landfill has been the primary dumping site for all municipal wastes, agricultural waste, commercial waste, and non-hazardous industrial waste in Bahrain. The Census Register of 2001 shows that around $94 \%$ of municipal waste generated is being disposed of at Asker Landfill. The study done by Consultant engineers [1] expected that Askar landfill to be reached the end of its operational life by 2016 based on the huge waste quantities generated and the space consumed each day. However, it's still operating and receiving municipal wastes.

Back to the census of 2011, one and half million tons of municipal wastes generated annually in the kingdom of Bahrain. These quantities are considered large for a small island like Bahrain with an area of $934.57 \mathrm{~km}^{2}$. Therefore, the study focuses on the wastes disposal; where the huge quantities of the municipal wastes that generated annually in Bahrain is an alarm to the public health and the space required for disposing these wastes. Hence, finding an alternative space in the very few coming years is becoming an essential issue as the expectations and the analysis studies showed that Askar landfill is reached its end life. In this situation, municipal wastes in Bahrain require full management program to find a proper solution, which deals with finding lands' alternatives for disposing municipal wastes and the criteria for selection new landfill's location.

The main objective of this study is to find out the most suitable land to be used as a municipal waste landfill. Furthermore, the study aims to develop a model for selection of landfill's location subject to the economic, social, and environmental constraints. It is also constrained by the possible transportation routes to deliver the wastes from Bahrain governorates to the proposed landfill.

\section{Literature Review}

Several researches had been carried out in several regions that concerned with the selection of municipal waste landfill. Most of these researches have used Multi-Criteria Decision Analysis (MCDA) and Global Information System (GIS). Few studies have used Statistical Data Analysis and other techniques.
Melo et al. [2] prepared a research on strategic decision analysis for selection of landfill sites. It aimed to relocate the landfill in the city of Cachoeiro de Itapemirim, Brazil using multi-criteria analysis and Geological Information Systems (GIS). To reduce the subjectivity in the decision, they developed an algorithm using final weights in pairwise comparisons to establish the relative importance of the variables. Charusiri and Ladachart [3] prepared a study on GIS application for the determination of geological barriers for landfill site selection in Songkhia Province of Thailand. The study was based on GIS model as a standard tool to search for high quality geological barriers suitable for landfill areas in the Songkhla region. The results of the study identified three maps for three barriers; lithological, clay and geological.

Chen [4] presented a study on data construction process and qualiflex-based method for multiple-criteria group decision making with interval-valued intuitionistic fuzzy sets. The methodology is focusing on detailed illustrations of how to apply the arithmetic calculations needed in the study without showing clear picture of a selection model for the landfill site. After implementing the long nonlinear programming, the results show the best order of the candidate landfill and the best choice. Bah and Tsiko [5] studied landfill site selection by integrating GIS and multi-criteria decision analysis for Freetown of Sierra Leone. The decision making was based on two major stages. In the first stage GIS model was used to exclude some locations due to the physical and environmental restrictions. In the second stage multi criteria analysis was used to examine the study area based on four factors: built-up areas; roads; water bodies; and degree of slope. Yesilnacar et al. [6] developed a study in Turkey on MSW landfill site selection for the city of Sanliurfa. It aimed to apply MCDA integrated with GIS to select possible sites for MSW landfill. The selection process used the fundamental of MCDA and the simple additive weighting (SAW) approach throughout the analyses. The open ended finding of

${ }^{*}$ Corresponding author: Mariam Aamer Khalil, Department of Mechanical Engineering, College of Engineering, University of Bahrain, Isa Town, P. O. Box 32038, Bahrain, Tel: +973 815-1438-3480; E-mail: mariam.aamer88@gmail.com

Received November 06, 2017; Accepted November 20, 2017; Published November 27, 2017

Citation: Khalil MA, Suliman SMA (2017) Municipal Waste Landfill Site Selection Model for Bahrain. Int J Waste Resour 7: 312. doi: 10.4172/2252-5211.1000312

Copyright: $\odot 2017$ Khalil MA, et al. This is an open-access article distributed under the terms of the Creative Commons Attribution License, which permits unrestricted use, distribution, and reproduction in any medium, provided the original author and source are credited. 
three possible alternatives rather than single site appears as a weakness in the study.

Agaji and Wajiga [7] presented a study on an object oriented system for the location of landfills for Nigerian municipals. The selected modeling approach was mathematical programming, it begins with translating the design into a form that can be coded into a computer system for execution. Strength of the study was in the design phase of the sites' selection process and the stages of selection method. In other hand, the weakness of the study was in the beginning of the selection as the selection done randomly. In Serbia, Bronja and Bronja [8] prepared a research aimed to preserve the environment and meeting several criteria such as communal and economic criteria for finding the optimal site. The research was based on multi-criteria analysis. Maximal value as a product of the weight of each criterion and its value was established. The obtained values were used for ranking of landfills. Then, the AHP was used to find out the optimal site based on multicriteria site selection.

Shah and Wani [9] presented a study for Srinagar city of India based on multi-criteria analysis and GIS to select the suitable site for waste disposal. The methodology incorporated many environmental and socio-economic parameters that were essential to identify the sites, which had minimum adverse impact on environment. Geospatial technology helped in the generation of information on different aspects like land use, road, slope, etc., which were used as criteria for the study. Ghoseiri and Lessan [10] used pairwise comparison and ELECTRE approaches for selection among five alternative waste disposal sites based on five major criteria. The major criteria involved in the study are environmental issues, economic issues, social concerns, political issues, and agricultural issue, which were divided further to several criteria. After implementing the methodology, the sites were ranked and the best site was tested by sensitivity analysis to take the final decision.

In parallel to the literature from various countries around the world and belonging to several periods within the last ten years, selection of suitable landfill site in Bahrain will definitely be based on multi criteria analysis to enhance the decision making as most of the literature have applied. In the other hand, the best methodology is difficult to be specified, since either Analytical Hierarchical Process or Fuzzy Set Analysis can be applied. However, the two methodologies will be used to select landfill site for Kingdom of Bahrain, by doing so the decision making will be enhanced.

\section{Data Collection and Problem Formulation}

The main data sources available are the previous studies done by Ministry of Works (MOW) and other engineering consultants who provide studies for the benefit of MOW. These studies are mainly about the existing landfill at Askar. The other sources of information available about the existing landfill are two reports prepared by MOW; these reports are dated back to 1988 and 1993. However, these reports have been considered in the most recent report prepared by O'Donovan [1]. The first report is "Review of Waste Disposal Operations at Askar landfill Site" which prepared by Central Municipal Council Environment Health Directorate, 1988. The second one is the factual report entitled "Site Investigation Report for Askar landfill" of the year 1993. These two reports and that prepared by O'Donovan are important because they provide an overview of the operations and geotechnical status of Askar landfill and surrounding areas.
The procedure of the study starts by discussions with official authorities in the kingdom of Bahrain to identify and define the landfill site selection criteria and the potential alternative landfill sites. Further to the discussions, it has been suggested to select an area within the blue zone around the existing landfill at Askar as illustrated in the latest land use map [11]. The blue zone surrounding the existing landfill at Askar is defined as Community Services land. This type of lands has a total of $8.04 \%$ of Bahrain area as per the National Plan of Kingdom of Bahrain for 2030. Based on these suggestions and discussions, five alternative sites have been defined, each with an area of $1.71 \mathrm{~km}^{2}$ or more, this area is based on the estimation of landfilling MSW for the coming 15 years. All these sites are located in the blue zone area and near to the existing landfill as shown in Figure 1. Figure 2 shows the five alternatives for landfill site within the selected zone.

After defining the landfill sites alternatives, discussions and reviews of similar research have been under taken to decide on the study criteria for selecting the best alternative. The outcome of reviewing and analysis for selecting an adequate selection criteria for decision making on the best landfill site is presented in Table 1. The main data required for studying the problem are distances from the proposed landfill sites (alternatives) to the defined areas, which considered as the main criteria. Google maps were used to collect data for criterion no. 1: Average path taken (road network), whereas, Google earth was used for finding distances of the rest criteria. All distances for the different criteria are combined in Table 2.

\section{Methodology}

Two analytical methods were suggested for this study; fuzzy set theory (FST) and analytical hierarchical process (AHP). These two methodologies have been highly recommended for multi-criteria decision making problems. The reason of selecting two methodologies is to enhance the study and support the final decision to be taken. A comparison between the two results will ensure the final decision of selecting the best landfill site.

\section{Fuzzy multi-criteria hierarchy process (FMHP)}

FMHP considers the fuzziness of the factors affecting site selection problem. FST is mainly based on defining the alternatives and criteria for such selection problem [12]. It requires to formulate the alternatives versus criteria matrix. Rating the criteria for each alternative site

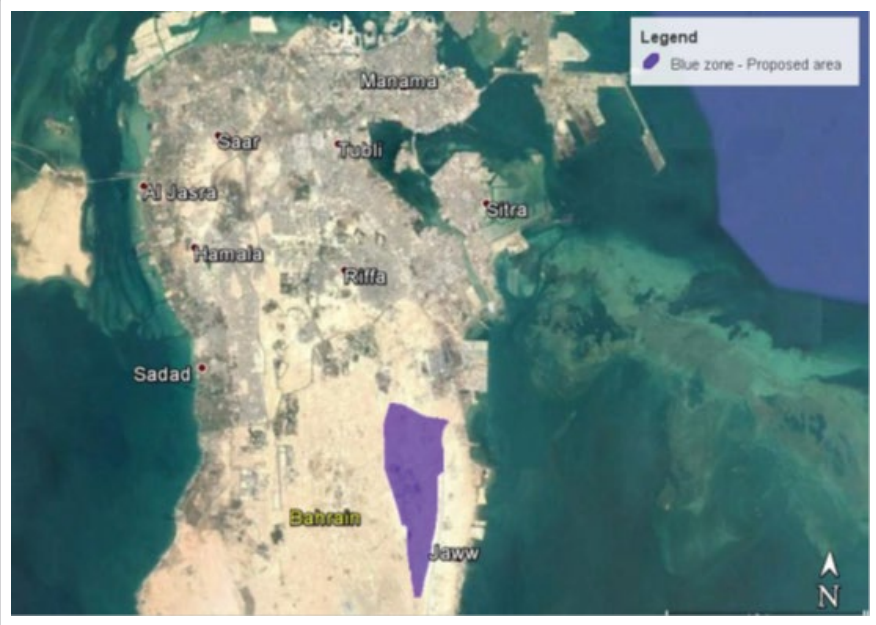

Figure 1: Selected zone for future landfill. 


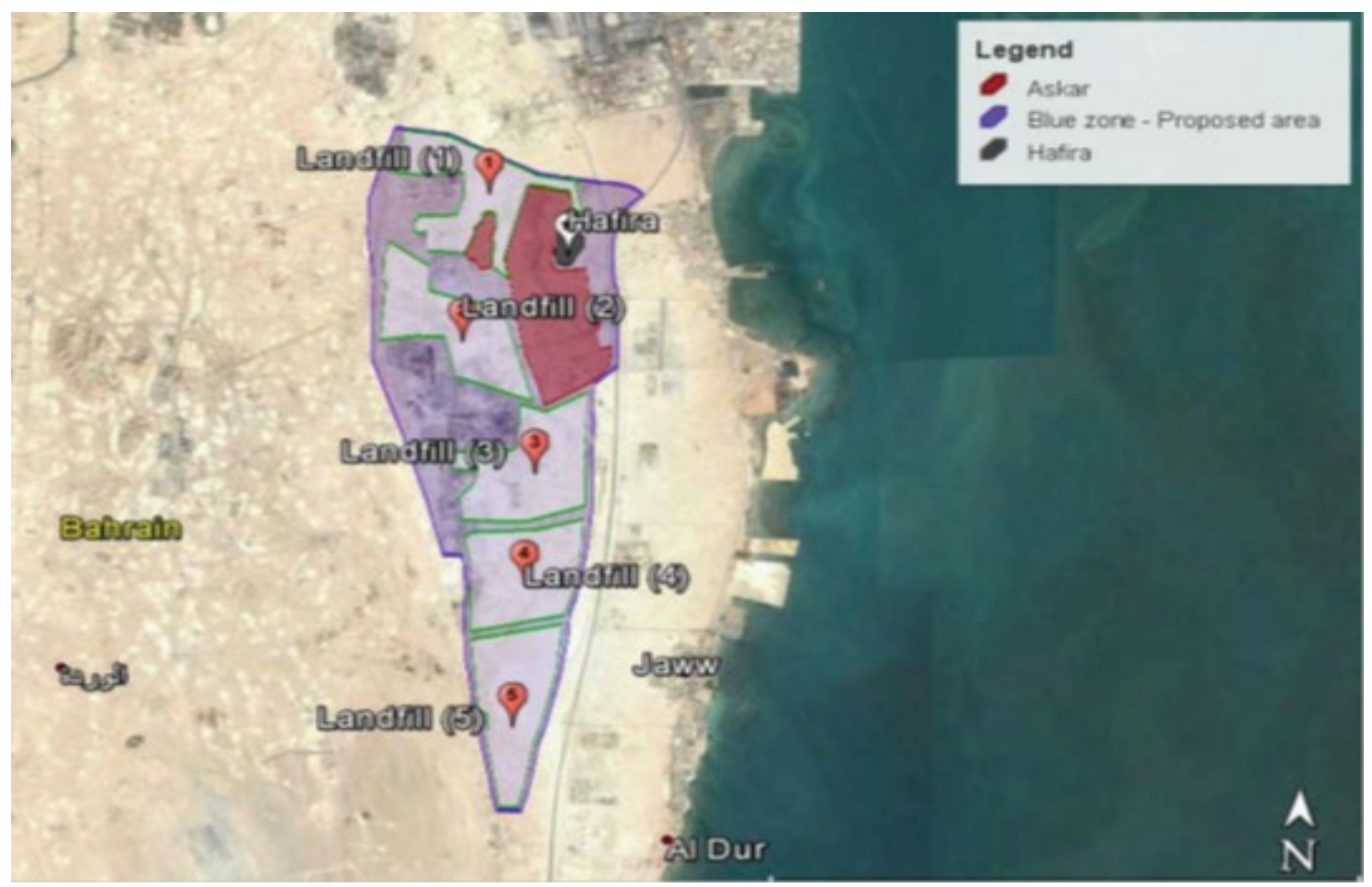

Figure 2: Landfill sites' alternatives.

\begin{tabular}{|c|c|}
\hline No. & Criteria \\
\hline $\mathrm{C}_{1}$ & Average path taken (Road network) \\
\hline $\mathrm{C}_{2}$ & Distance from residential areas \\
\hline $\mathrm{C}_{3}$ & Distance from agricultural land \\
\hline $\mathrm{C}_{4}$ & Industrial areas \\
\hline $\mathrm{C}_{5}$ & Existing Bapco Oil Field \\
\hline $\mathrm{C}_{6}$ & Distance to the Oil Pipeline \\
\hline $\mathrm{C}_{7}$ & Preserved areas \\
\hline $\mathrm{C}_{8}$ & Bahrain International Circuit \\
\hline $\mathrm{C}_{9}$ & Proposed Bahrain -Qatar Causeway \\
\hline $\mathrm{C}_{10}$ & Military Airports \\
\hline $\mathrm{C}_{11}$ & Military Camps \\
\hline
\end{tabular}

Table 1: Selected criteria.

\begin{tabular}{|c|c|c|c|c|c|c|c|c|c|c|c|}
\hline \multirow[b]{2}{*}{ 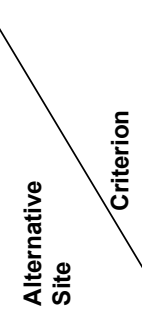 } & \multirow{2}{*}{ 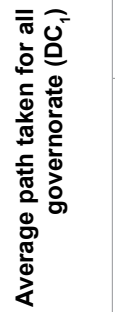 } & \multicolumn{10}{|c|}{ Distance from: } \\
\hline & & 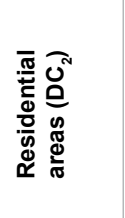 & 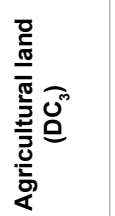 & 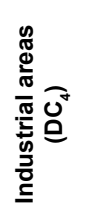 & 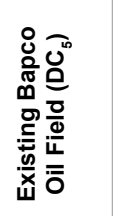 & 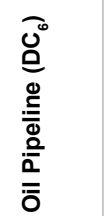 & 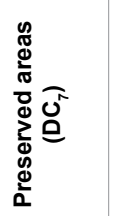 & 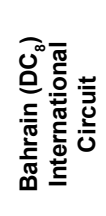 & 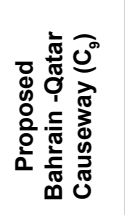 & 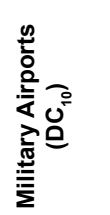 & 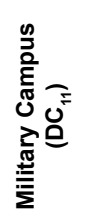 \\
\hline Landfill (1) & 27.60 & 0.51 & 7.6 & 0.16 & 9.29 & 0.03 & 5.01 & 6.50 & 5.69 & 4.57 & 2.59 \\
\hline Landfill (2) & 26.94 & 1.46 & 7.68 & 1.80 & 7.95 & 0.12 & 3.36 & 6.10 & 7.00 & 4.20 & 2.41 \\
\hline Landfill (3) & 27.90 & 0.89 & 9.14 & 3.12 & 6.93 & 0.95 & 1.47 & 6.73 & 6.65 & 5.11 & 3.52 \\
\hline Landfill (4) & 29.37 & 0.7 & 8.19 & 3.42 & 6.28 & 1.08 & 0.24 & 7.00 & 7.85 & 5.33 & 3.83 \\
\hline Landfill (5) & 30.80 & 0.43 & 7.99 & 4.13 & 4.73 & 2.68 & 0.14 & 7.48 & 9.08 & 3.05 & 4.45 \\
\hline
\end{tabular}


Citation: Khalil MA, Suliman SMA (2017) Municipal Waste Landfill Site Selection Model for Bahrain. Int J Waste Resour 7: 312. doi: 10.4172/2252-

is achieved by dividing the distances of Table 2 using the following equation:

$$
\mathrm{X}_{\mathrm{ij}, \text { landfill(k) }}^{\mathrm{R}}=\mathrm{DC}_{\mathrm{i}} / \mathrm{DC}_{\mathrm{j}}
$$

Where $\mathrm{X}_{\mathrm{i}, \text { landfill(k) }}^{\mathrm{R}}$ is the ratio of distance of criteria $\mathrm{i}$ to distance of criteria $j$ for landfill $(k), D_{i}$ and $\mathrm{DC}_{j}$ are distances of criteria $\mathrm{C}_{\mathrm{i}}$ and $\mathrm{C}_{\mathrm{j}}$, respectively.

An example for such calculation of $\mathrm{X}^{\mathrm{R}}{ }_{12, \text { landfill(1) }}$ for landfill (1) using the values of DC1 and DC2 from Table 2 is:

$$
\mathrm{X}_{12 \text {, landfill }(1)}^{\mathrm{R}}=27.06 / 0.51=54.11
$$
(1)

Table 3 shows, as an example, the Criteria Ratios Matrix for landfill

After that, the rating matrix is converted to the judgment matrix based on Saaty's scale and inverses measures shown in Table 4 [13].

The measures are used to evaluate the ratios in Table 3 by taking the rounded value of the ratio and wherever the values above 9 is taken as 9 , and any values less than 0.11 is taken as 0.11 , taking into consideration that any cell and its inverse (i.e., $\mathrm{X}^{\mathrm{R}}{ }_{12}$ ' landfill(1) and $\mathrm{X}^{\mathrm{R}}{ }_{21}$, landfill(1) ) should have the original scale on one of them and its inverse on the other. Table 5 shows, as an example, the Criteria Judgement Matrix for landfill (1).

After creating the Criteria Judgment Matrix based on Saaty's scale, the FMHP first step starts by constructing the Fuzzy Judgment Matrix using triangular fuzzy numbers $(\mathrm{L}, \mathrm{M}, \mathrm{U})$ defined by Ghoseiri and Lessan [10].

$$
\begin{aligned}
& \mathrm{X}_{\mathrm{ij}, \text { landfill(k) }}=(\mathrm{Lij}, \mathrm{Mij}, \mathrm{Uij}) \\
& \mathrm{X}_{\mathrm{j}, \text { landfill(k) }}=(1 / \mathrm{Uij}, 1 / \mathrm{Mij}, 1 / \mathrm{Lij}), \text { for } \mathrm{i}, \mathrm{j}=1,2, \ldots, \mathrm{n} \text { and }(\mathrm{i} \neq \mathrm{j})
\end{aligned}
$$

Where $\mathrm{n}$ is the number of criteria.

Also, Table 6 can be used to establish these triangular numbers.

Thus, for example the fuzzy numbers for criteria 1 and 3 of landfill (1) are given by:

$$
\begin{aligned}
\mathrm{X}_{13, \text { landfill(1) }} & =(4-1,4,4+1) \\
& =(3,4,5)
\end{aligned}
$$

Where number 4 represents the medium.

While for criteria 3 and 1 of landfill (1) are:

$$
\begin{aligned}
X_{31, \text { landfill(1) }} & =(1 / 5,1 / 4,1 / 3) \\
& =(0.2,0.25,0.33)
\end{aligned}
$$

The Fuzzy Judgment Matrix for the alternative site landfill (1) with

\begin{tabular}{|c|c|c|c|c|c|c|c|c|c|c|c|c|}
\hline Sites & Criteria & $C_{1}$ & $\mathrm{C}_{2}$ & $\mathrm{C}_{3}$ & $\mathrm{C}_{4}$ & $\mathrm{C}_{5}$ & $\mathrm{C}_{6}$ & $C_{7}$ & $\mathrm{C}_{8}$ & $\mathrm{C}_{9}$ & $\mathrm{C}_{10}$ & $C_{11}$ \\
\hline \multirow{11}{*}{ Landfill (1) } & $\mathrm{C}_{1}$ & 1 & 54.11 & 3.63 & 172.49 & 2.97 & 919.93 & 5.51 & 4.25 & 4.85 & 6.04 & 10.66 \\
\hline & $\mathrm{C}_{2}$ & 0.02 & 1 & 0.07 & 3.19 & 0.05 & 17.00 & 0.10 & 0.08 & 0.09 & 0.11 & 0.20 \\
\hline & $\mathrm{C}_{3}$ & 0.28 & 14.90 & 1 & 47.50 & 0.82 & 253.33 & 1.52 & 1.17 & 1.34 & 1.66 & 2.93 \\
\hline & $\mathrm{C}_{4}$ & 0.01 & 0.31 & 0.02 & 1 & 0.02 & 5.33 & 0.03 & 0.02 & 0.03 & 0.04 & 0.06 \\
\hline & $\mathrm{C}_{5}$ & 0.34 & 18.22 & 1.22 & 58.06 & 1 & 309.67 & 1.85 & 1.43 & 1.63 & 2.03 & 3.59 \\
\hline & $\mathrm{C}_{6}$ & 0.00 & 0.06 & 0.00 & 0.19 & 0.00 & 1 & 0.01 & 0.00 & 0.01 & 0.01 & 0.01 \\
\hline & $C_{7}$ & 0.18 & 9.82 & 0.66 & 31.31 & 0.54 & 167.00 & 1 & 0.77 & 0.88 & 1.10 & 1.93 \\
\hline & $\mathrm{C}_{8}$ & 0.24 & 12.75 & 0.86 & 40.63 & 0.70 & 216.67 & 1.30 & 1 & 1.14 & 1.42 & 2.51 \\
\hline & $C_{9}$ & 0.21 & 11.16 & 0.75 & 35.56 & 0.61 & 189.67 & 1.14 & 0.88 & 1 & 1.25 & 2.20 \\
\hline & $\mathrm{C}_{10}$ & 0.17 & 8.96 & 0.60 & 28.56 & 0.49 & 152.33 & 0.91 & 0.70 & 0.80 & 1 & 1.76 \\
\hline & $\mathrm{C}_{11}$ & 0.09 & 5.08 & 0.34 & 16.19 & 0.28 & 86.33 & 0.52 & 0.40 & 0.46 & 0.57 & 1 \\
\hline
\end{tabular}
respect to each criterion is shown in Table 7.

In the FMHP second step priority vectors are calculated for the triangular fuzzy comparison matrix, a normalization formula is used as follow:

$$
\begin{gathered}
\left.\tilde{X}_{i j}=\text { (Lower bound, Medium bound, Upper bound }\right) \\
\tilde{X}_{i j}=\left(\frac{\sum_{i=1}^{n} \sum_{j=1}^{m} L_{i j}}{\sum_{i=1}^{n}\left(\sum_{j=1}^{m} \sum_{i=1}^{n} U_{i j}\right)}, \frac{\sum_{i=1}^{n} \sum_{j=1}^{m} M_{i j}}{\sum_{i=1}^{n}\left(\sum_{j=1}^{m} \sum_{i=1}^{n} M_{i j}\right)}, \frac{\sum_{i=1}^{n} \sum_{j=1}^{m} U_{i j}}{\sum_{i=1}^{n}\left(\sum_{j=1}^{m} \sum_{i=1}^{n} L_{i j}\right)}\right)
\end{gathered}
$$

Where $\mathrm{m}$ is the number of alternatives.

Table 3: Criteria ratios matrix $\left(X_{i j}^{r}\right)$ for landfill (1).

\begin{tabular}{|c|c|c|}
\hline Scale of importance & Saaty's scale & Inverse of Saaty's scale \\
\hline Equally important & 1 & 1.00 \\
\hline & 2 & 0.50 \\
\hline & & 1 \\
\hline & 3 & 0.33 \\
\hline Obviously important important & 4 & 0.25 \\
\hline & 5 & 0.20 \\
\hline Intensively important & 6 & 0.17 \\
\hline & 7 & 0.14 \\
\hline & 8 & 0.13 \\
\hline
\end{tabular}

Table 4: Saaty's scale and inverses measures. 


\begin{tabular}{|c|c|c|c|c|c|c|c|c|c|c|c|c|}
\hline Sites & Criteria & $C_{1}$ & $\mathrm{C}_{2}$ & $\mathrm{C}_{3}$ & $\mathrm{C}_{4}$ & $C_{5}$ & $\mathrm{C}_{6}$ & $C_{7}$ & $\mathrm{C}_{8}$ & $\mathrm{C}_{9}$ & $C_{10}$ & $C_{11}$ \\
\hline \multirow{11}{*}{ Landfill (1) } & $\mathrm{C}_{1}$ & 1 & 9 & 4 & 9 & 3 & 9 & 6 & 4 & 5 & 6 & 9 \\
\hline & $\mathrm{C}_{2}$ & 0.11 & 1 & 0.11 & 3 & 0.11 & 9 & 0.11 & 0.11 & 0.11 & 0.11 & 0.2 \\
\hline & $\mathrm{C}_{3}$ & 0.25 & 9 & 1 & 9 & 1 & 9 & 2 & 1 & 1 & 2 & 3 \\
\hline & $\mathrm{C}_{4}$ & 0.11 & 0.33 & 0.11 & 1 & 0.11 & 5 & 0.11 & 0.11 & 0.11 & 0.11 & 0.11 \\
\hline & $\mathrm{C}_{5}$ & 0.33 & 9 & 1 & 9 & 1 & 9 & 2 & 1 & 2 & 2 & 4 \\
\hline & $\mathrm{C}_{6}$ & 0.11 & 0.11 & 0.11 & 0.2 & 0.11 & 1 & 0.11 & 0.11 & 0.11 & 0.11 & 0.11 \\
\hline & $C_{7}$ & 0.17 & 9 & 0.5 & 9 & 0.5 & 9 & 1 & 1 & 1 & 1 & 2 \\
\hline & $\mathrm{C}_{8}$ & 0.25 & 9 & 1 & 9 & 1 & 9 & 1 & 1 & 1 & 1 & 3 \\
\hline & $\mathrm{C}_{9}$ & 0.2 & 9 & 1 & 9 & 0.5 & 9 & 1 & 1 & 1 & 1 & 2 \\
\hline & $C_{10}$ & 0.17 & 9 & 0.5 & 9 & 0.5 & 9 & 1 & 1 & 1 & 1 & 2 \\
\hline & $C_{11}$ & 0.11 & 5 & 0.33 & 9 & 0.25 & 9 & 0.5 & 0.33 & 0.5 & 0.5 & 1 \\
\hline
\end{tabular}

Table 5: Criteria judgment matrix $\left(X_{i j}^{j}\right)$ for landfill (1).

\begin{tabular}{|c|c|c|}
\hline Saaty's measure & Lower (L) & Medium (M) \\
\hline Exact number 1 & 1 & 1 \\
\hline Approximate 1 & 1 & 1 \\
\hline$X=\{2$ to 8$\}$ & $X-1$ & (U) \\
\hline Approximate 9 & 8 & 9 \\
\hline $1 / X$ & $1 /(X+1)$ & 9 \\
\hline $1 /(9)$ & 0.11 & $1 / \mathrm{X}+1$ \\
\hline
\end{tabular}

Table 6: The fuzzy triangular numbers.

Equation (4) is used twice, first for finding the weight for each criterion $\left(\mathrm{W}_{\mathrm{i}}\right)$, and then for finding the priorities for each alternative with respect to each criterion $\left(\mathrm{P}_{\mathrm{ki}}\right)$, where $(\mathrm{i})$ is the criterion and $(\mathrm{k})$ is the alternative. Following are samples for calculating $\mathrm{W}_{\mathrm{i}}$ and $\mathrm{P}_{\mathrm{ki}}$ :

$\mathbf{W}_{1}=([1+1+1+1+1+8+\ldots .+6] /[1+0.13+\ldots .+0.17+9+\ldots .+1]$, $[1+1+\ldots \ldots+7] /[1+0.11+\ldots . .+1+1],[1+1+\ldots . .+9+8] /[1+0.11+\ldots . .+1+1]$ $=(0.164,0.231,0.301)$

$\mathbf{P}_{11}=([1+8+\ldots+8] /[1+0.13+\ldots+3+1], \quad[1+9+\ldots \ldots+9] /$ $[1+0.11+\ldots .+2+1],[1+9+\ldots .+9] /[1+0.11+\ldots .+1+1]=(0.145,0.195$, $0.248)$

Table 8 shows the results of the derived priorities for all alternatives and criteria.

The third step in FMHP is estimating $\alpha$-cut, which is the confidence level of decision maker, where: $\alpha \in[0,1]$. By defining $\alpha$-cut the initial fuzzy triangular number $(\mathrm{L}, \mathrm{M}, \mathrm{U})$ is converted to fuzzy number with two bounds $\left(\mathrm{X}^{\mathrm{L}}, \mathrm{X}^{\mathrm{U}}\right)$ defined by:

$$
\begin{aligned}
& \mathrm{X}^{\mathrm{L}}=\mathrm{L}+(\mathrm{M}-\mathrm{L}) \alpha \\
& \mathrm{X}^{\mathrm{U}}=\mathrm{U}-(\mathrm{U}-\mathrm{M}) \alpha
\end{aligned}
$$

A larger a value indicates more confident decision maker. As the study relies on two methodologies to take the final decision not only fuzzy set, the level of confidence is evaluated at $50 \%$. For example, the fuzzy number bounds of the weight of criterion (1) are:

$$
\mathrm{X}^{\mathrm{L}}(\mathrm{W} 1)=0.164+[(0.231-0.164) \times 0.5]=0.195
$$

and

$$
\mathrm{X}^{\mathrm{U}}(\mathrm{W} 1)=0.301-[(0.301-0.231) \times 0.5]=0.265
$$

Whereas, the fuzzy number bounds of rating of landfill (1) w.r.t. criterion (1) are obtained as follows:

$$
\mathrm{X}^{\mathrm{L}}(\mathrm{P} 11)=0.145+[(0.195-0.145) \times 0.5]=0.170
$$

and

$$
\mathrm{X}^{\mathrm{U}}(\mathrm{P} 11)=0.248-[(0.248-0.195) \times 0.5]=0.222
$$

The last step is to estimate degree of optimism $\lambda$, where: $\lambda \epsilon[0,1]$. The degree of optimism is varying, and it depends on the accuracy of data collected and expectations of changes in the coming years. Moderate degree of optimism is suggested for the study. That will lead to get the real decision making matrix for the criteria and alternative, by combining steps 3 and 4 , the final weight can be expressed as:

$$
\mathrm{X}=\lambda \mathrm{X}^{\mathrm{U}}+(1-\lambda) \mathrm{X}^{\mathrm{L}}
$$

Sample of calculations to produce the final weight of criterion (1), and rating of landfill (1) w.r.t criterion (1) with a value of $\lambda$ equal to 0.5 :

$$
\begin{aligned}
& X\left(W_{1}\right)=(0.5 \times 0.265)+[(1-0.5) \times 0.195]=0.232 \\
& X\left(P_{11}\right)=(0.5 \times 0.222)+[(1-0.5) \times 0.170]=0.196 .
\end{aligned}
$$

The final comparison matrix is presented in Table 9.

The last stage is to evaluate the alternative sites using the average weighted concept, and then to rank the final results. The alternative average weight is given by:

Average weight ${ }_{\text {(Landfill i) }}=\Sigma_{\text {for all criteria }}$ (Criterion weight $\mathrm{x}$ Alternative weight associated with the criterion)

$$
A W_{k}=\sum_{i=1}^{n} W_{i} \times P_{k i}
$$

Where, $\mathrm{AW}_{\mathrm{k}}$ is the average weight of alternative $\mathrm{k}$.

An example of the calculation for landfill (1) is illustrated below:

$\mathrm{AW}_{1}=(0.232 \times 0.196)+(0.03 \times .042)+(0.124 \times .118)+(0.06 \times$ $0.022)+(0.114 \times 0.123)+(0.027 \times 0.007)+(0.046 \times 0.105)+(0.114 \times$ $0.113)+(0.115 \times 0.108)+(0.093 \times 0.105)+(0.077 \times 0.081)=0.1231$

Evaluations of the alternative sites is summarized in Table 10.

The ranking weights for the five alternatives as shown in Table 10 are too close to each other where the highest weight is 0.1391 for landfill (3) and the lowest is 0.1231 for landfill (1). The range of variation between the average weights of these two alternatives is equal to 0.016 . This small variation indicates that the five alternative sites have almost the same preference, and therefore all of them are suitable to be utilized 


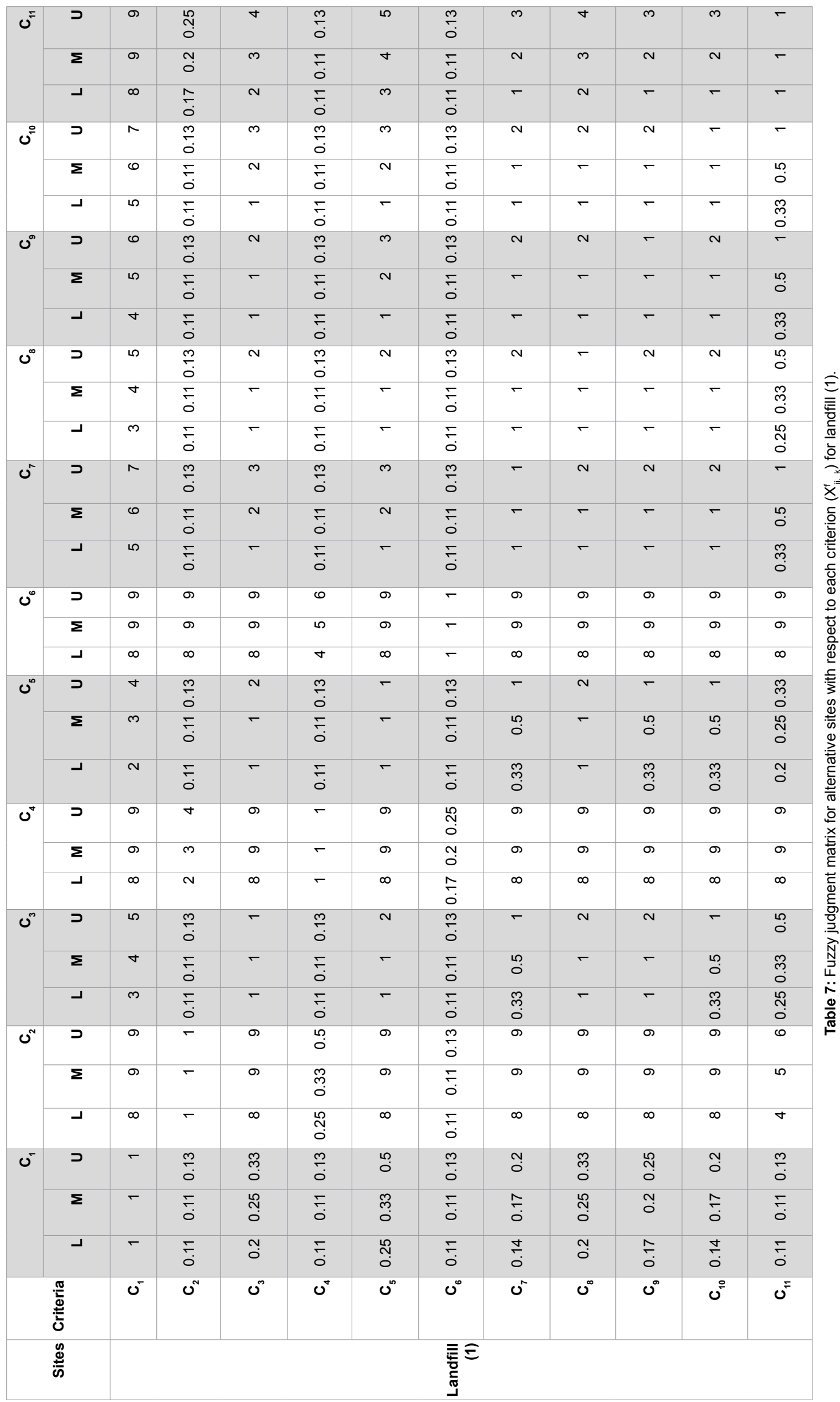




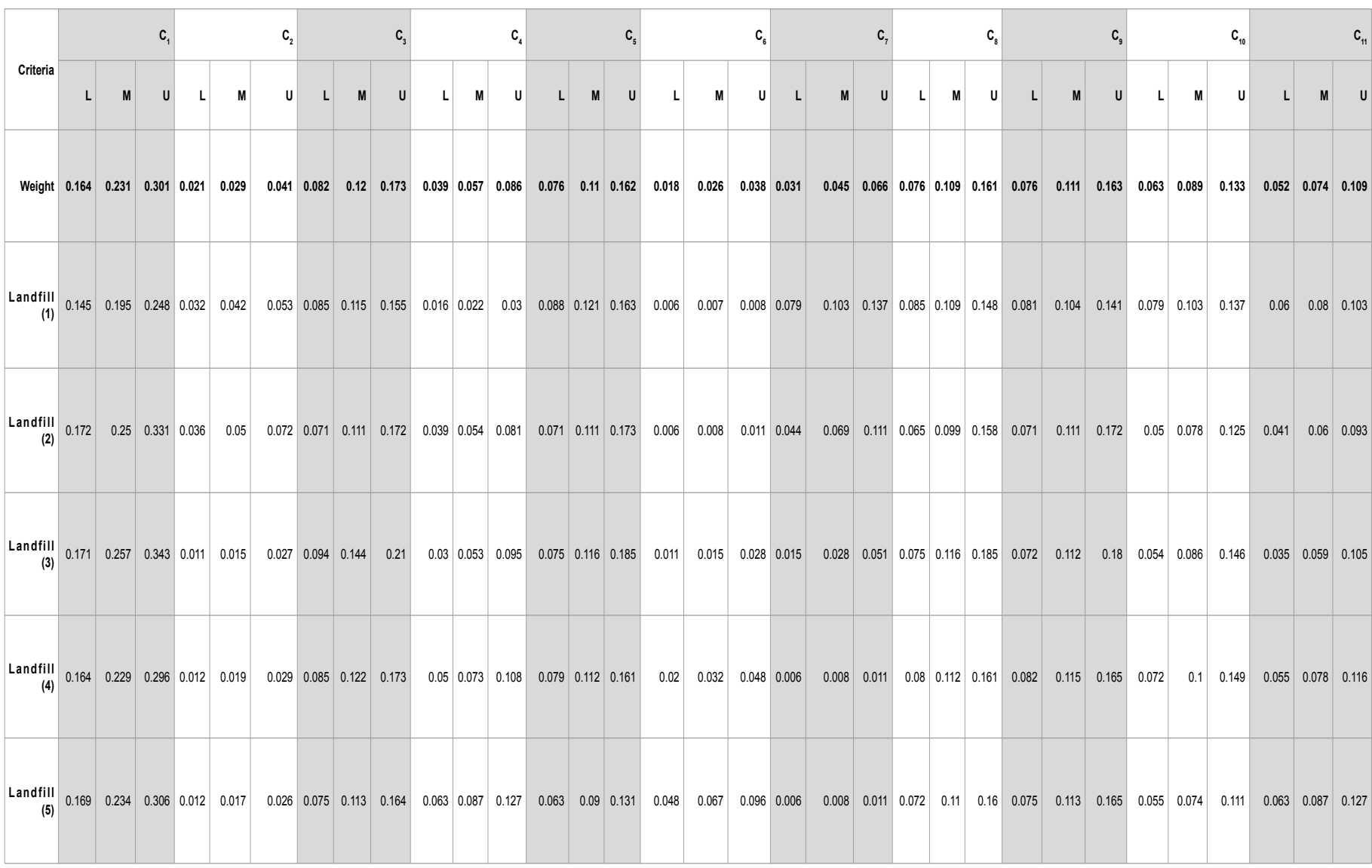

Table 8: Fuzzy weights and priorities judgment matrix for criteria and alternatives.

as a landfill site. This is an expected result because all the alternatives are located in the same zone.

\section{Analytical Hierarchical Process (AHP)}

AHP is an algorithm to solve kind of problems that can be decomposed into hierarchical structure. The structure usually consists of an objective of what need to be resolved, problem alternatives, and criteria to justify the selection between these alternatives [13]. The outcome of AHP ranks the alternatives, and the option in the first rank is considered as the best alternative. It's procedure consists of three basic stages.

\section{First stage: development of weights for the criteria}

At this stage, a single pair wise comparison matrix is established for the weights of criteria by calculating comparison ratios based on the distances of each criterion as given in the Criteria Ratios Matrix of Table 3. After that, the ratios' matrix is converted to the Criteia Judgment Matrix based on Saaty's scale, which is presented in Table 5.

As criteria have the same preference in the study where the aim is to find the best site alternative relative to the distances for each criterion, developing weights for the criteria are based on taking the average for each pair of criteria in the criteria judgment matrix for all the five landfills alternatives presented in Table 5. Therefore, the weights of the criteria matrix (Xij) are obtained by the following Equation:

$\mathrm{Xij}=$ Average of values of criteria $\mathrm{i}$ and $\mathrm{j}$ in the criteria judgment matrix for all landfill alternatives
The values in each row in Table 11 are multiplied and the $\mathrm{n}^{\text {th }}$ root of each criterion is calculated (where $\mathrm{n}$ is the number of criteria). This is done by the following Equation:

$$
\mathrm{n}^{\text {th }} \operatorname{root}(\mathrm{Ci})=\prod_{i=1}^{n}(\mathrm{Xij}) \wedge\left(\frac{1}{n}\right)
$$

Where, $\mathrm{Ci}$ is criterion (i).

Applying the Equation for criterion (1):

$11^{\text {th }} \operatorname{root}\left(\mathrm{C}_{1}\right)=(1 \times 9 \times 3.8 \times 8.6 \times 4.4 \times 9 \times 8.2 \times 4 \times 4 \times 6.4 \times 8.2)$ $\wedge(1 / 11)=5.23$

Then, the aforementioned $\mathrm{n}^{\text {th }}$ root is normalized to get the appropriate weight or priority vector (PV) for each criterion by using:

$$
\operatorname{PV}(C i)=n^{\text {th }} \operatorname{root}(C i) / \sum_{(i=1)}^{n} n^{\text {th }} \operatorname{root}(C i)
$$

Thus, $\mathrm{PV}\left(\mathrm{C}_{1}\right)$ is obtained as follows:

$$
\operatorname{PV}\left(\mathrm{C}_{1}\right)=5.23 / 17.42=0.30
$$

The criteria $11^{\text {th }}$ roots as well as the priority vectors are included in Table 11.

The last part of this stage is calculating and checking the Consistency Ratio (CR). CR gives an idea to the decision maker of whether the analysis is consistent or not. The CR is calculated by applying the following five steps:

1. The summation of each column in Table 11, designated $\left(\operatorname{Sum}\left(C_{i}\right)\right)$, is established.

The results are tabulated in Table 11. 
2. $\quad$ Each $\operatorname{Sum}\left(\mathrm{C}_{\mathrm{i}}\right)$ is then multiplied by the respective weight for $\mathrm{C}_{\mathrm{i}}$, i.e., Priority Vector $\left(\mathrm{PV}\left(\mathrm{C}_{\mathrm{i}}\right)\right)$, to obtain $(\operatorname{SumPV}(\mathrm{Ci}))$ :

$$
\operatorname{SumPV}(\mathrm{Ci})=\operatorname{Sum}(\mathrm{Ci}) * \mathrm{PV}(\mathrm{Ci})
$$

For example, the calculation for criteria 1 is:

$$
\operatorname{SumPV}(\mathrm{C} 1)=2.77 \times 0.30=0.83
$$

3. Find Lambda-max $(\lambda \max )$ by adding all values calculated in the previous step

$$
\lambda \max =\sum_{\forall \text { criteraialateranatives }}(\operatorname{SumPV}(\mathrm{Ci}))
$$

Thus, $\lambda \max =0.83+1.22+1.11+1.55+1.19+1.27+1.87+1.09$ $+1.12+1.27+1.31=13.86$

4. Calculate Consistency index (CI)

$$
\mathrm{CI}=(\lambda \max -\mathrm{n}) /(\mathrm{n}-1)
$$

Where, $\mathrm{n}$ is the number of criteria.

$$
\text { Thus, } \quad \mathrm{CI}=(13.86-11) /(11-1)=0.286
$$

5. Then the Consistency Ratio (CR) is then calculated by dividing CI by a Random Index (RI) obtained from Table 12 .

$$
\mathrm{CR}=\mathrm{CI} / \mathrm{RI}
$$

the Random Index (RI) from Table 12 is equal to 1.51 for a matrix size of 11 . Thus,

$$
\mathrm{CR}=0.286 / 1.51=0.189
$$

Based on the above results as shown in Table 11, CR is greater than 0.10 which is not acceptable and the matrix is considered as inconsistent. Therefore, the analysis needs to be redone.

Second round of analysis: The second suggestion for developing the weights for the criteria is based on the range of variations in the distances between alternative sites and criteria. The ranges are obtained by applying the following equation to the distances of Table 2 :

$\Delta$ distance $\left(\mathrm{C}_{\mathrm{i}}\right)=$ maximum distance - minimum distance

Thus, for criterion 1 and 2 , the ranges are given by:

$\Delta$ distance $\left(\mathrm{C}_{1}\right)=30.80-26.94=3.86$

$\Delta$ distance $\left(\mathrm{C}_{2}\right)=1.46-0.43=1.03$

Based on the calculated ranges of distances for each criterion, a pair wise comparison matrix of criteria weights can be created by calculating the ratios between criteria using:

$$
\mathrm{Xij}=\Delta \text { distance }(\mathrm{Ci}) / \Delta \text { distance }(\mathrm{Cj})
$$

For example, the ratio between criteria (1) and (2) is given by:

$$
\mathrm{X}_{12}=3.86 / 1.03=3.75
$$

After that, the ratios are converted into Saaty's measures and the same steps done in the first round of analysis are repeated, and the results are shown in Table 13. Based on these results, CR is less than $0.10(\mathrm{CR}=0.01)$ which is highly consistent as it is small. Therefore, the analysis is acceptable and the weights of criterion can be used in the third stage of AHP [14-17].

\section{Second stage: development ratings for landfill alternative sites}

In this stage of AHP procedure ratings are developed for each decision alternative for each criterion. At this step a pair wise comparison matrix for each criterion is created with each matrix containing the performance of decision alternatives on that criterion. Here, basically the ratings of the alternatives are based on the distances from the criteria to the proposed landfill sites. Thus, the rating of decision alternative (i) relative to alternative $(j)$

(Xij) for each criterion is given by:

Xij = Distance to landfill (i) / Distance to landfill (j)

For example, the rating of landfill (1) relative to landfill (2) based on criterion (1) is:

$$
\mathrm{X}_{12}\left(\mathrm{C}_{2}\right)=0.51 / 1.46=0.35
$$

All the relative ratings (Ratios Matrix) for the different alternatives based on criterion (2) and (3) are included in Table 14. Similarly, relative ratings for other criteria are prepared.

The same procedure used to find the ratings in the first stage is applied here for each decision alternative under each criterion. The CRs for alternatives' ratings are very consistent for all criteria, and they are ranging from 0 to a maximum of 0.06 . Therefore, no corrective action is necessary since all values are less than 0.10 . That gives a good indication of consistency on the alternative matrices and later on decision making. Table 15 shows, as an example, the results obtained for criterion (2).

\section{Third stage: weighted average ratings}

The weighted average rating is calculated for each decision alternative by combining the PV of all matrices created in stages one and two using the following equation:

$$
A W_{k}=\sum_{(i=1)}^{n} W_{i} \times P_{k i}
$$

Where, $\mathrm{AW}_{\mathrm{k}}$ is the average weight of landfill $(\mathrm{k}), \mathrm{W}_{\mathrm{i}}$ and $\mathrm{P}_{\mathrm{ki}}$ are the weights (i.e. PV) of the criteria (i) and landfill (k).

The following example shows the calculation of the average weight for Landfill (1):

$\mathrm{AW}_{1}=(0.13 \times 0.20)+(0.03 \times 0.13)+(0.05 \times 0.20)+(0.13 \times 0.03)$ $+(0.14 \times 0.23)+(0.09 \times 0.03)+(0.14 \times 0.038)+(0.04 \times 0.20)+(0.11 \times$ $0.17)+(0.07 \times 0.20)+(0.06 \times 0.17)=0.184$

The average weights are summarized in Table 16. They are used to rank the alternative sites, and select the best one with the highest score.

The final results of applying AHP approach are shown in Table 16. The highest score is for landfill (3), followed by landfills (2), (5), (4) and (1), respectively. The ranking weights for the five alternatives are close to each other, where the highest weight is 0.214 and the lowest is 0.184 , with a difference of 0.030 between them.

Table 17 shows the average weights and ranking results for all alternatives by both approaches. Landfill (3) has the highest weight by both approaches, followed by landfill (2). The third and fourth ranks are exchanged between landfills (4) and (5) alternatively by the two approaches as shown in the table. The last preference site is landfill (1).

\section{Conclusion}

It is preferred to select a landfill near the existing one from economical, operational, and environmental dimensions. Selection of the new landfill location away from the existing one will require extra cost for site preparation, extra operational cost, and extra 
Citation: Khalil MA, Suliman SMA (2017) Municipal Waste Landfill Site Selection Model for Bahrain. Int J Waste Resour 7: 312. doi: 10.4172/22525211.1000312

Page 9 of 11

\begin{tabular}{|c|c|c|c|c|c|c|c|c|c|c|c|}
\hline Criteria & $C_{1}$ & $\mathrm{C}_{2}$ & $\mathrm{C}_{3}$ & $\mathrm{C}_{4}$ & $\mathrm{C}_{5}$ & $\mathrm{C}_{6}$ & $\mathrm{C}_{7}$ & $\mathrm{C}_{8}$ & $\mathrm{C}_{9}$ & $C_{10}$ & $C_{11}$ \\
\hline Weight & 0.232 & 0.030 & 0.124 & 0.060 & 0.114 & 0.027 & 0.046 & 0.114 & 0.115 & 0.093 & 0.077 \\
\hline Landfill (1) & 0.196 & 0.042 & 0.118 & 0.022 & 0.123 & 0.007 & 0.105 & 0.113 & 0.108 & 0.105 & 0.081 \\
\hline Landfill (2) & 0.251 & 0.052 & 0.116 & 0.057 & 0.116 & 0.008 & 0.073 & 0.105 & 0.116 & 0.083 & 0.064 \\
\hline Landfill (3) & 0.257 & 0.017 & 0.148 & 0.058 & 0.123 & 0.018 & 0.031 & 0.123 & 0.119 & 0.093 & 0.064 \\
\hline Landfill (4) & 0.229 & 0.020 & 0.126 & 0.076 & 0.116 & 0.033 & 0.008 & 0.116 & 0.120 & 0.105 & 0.082 \\
\hline Landfill (5) & 0.236 & 0.018 & 0.116 & 0.091 & 0.094 & 0.069 & 0.008 & 0.113 & 0.117 & 0.078 & 0.091 \\
\hline
\end{tabular}

Table 9: Final comparison matrix $\left(\mathrm{X}\left(\mathrm{P}_{\mathrm{ij}}\right)\right)$.

\begin{tabular}{|c|c|c|}
\hline Alternative (k) & Average Weight & Ranking \\
\hline Landfill (1) & 0.1231 & 5 \\
\hline Landfill (2) & 0.1324 \\
\hline Landfill (3) & 0.1391 & 2 \\
\hline Landfill (4) & 0.1315 & 1 \\
\hline Landfill (5) & 0.1286 \\
\hline
\end{tabular}

Table 10: Alternative sites evaluation.

\begin{tabular}{|c|c|c|c|c|c|c|c|c|c|c|c|c|c|}
\hline Criteria & $C_{1}$ & $\mathrm{C}_{2}$ & $\mathrm{C}_{3}$ & $\mathrm{C}_{4}$ & $\mathrm{C}_{5}$ & $\mathrm{C}_{6}$ & $C_{7}$ & $\mathrm{C}_{8}$ & $\mathrm{C}_{9}$ & $C_{10}$ & $C_{11}$ & 11th root & PV \\
\hline $\mathrm{C}_{1}$ & 1 & 9.00 & 3.80 & 8.60 & 4.40 & 9.00 & 8.20 & 4.00 & 4.00 & 6.40 & 8.20 & 5.23 & 0.30 \\
\hline $\mathrm{C}_{2}$ & 0.11 & 1 & 0.13 & 0.91 & 0.13 & 3.93 & 1.42 & 0.14 & 0.13 & 0.18 & 0.25 & 0.34 & 0.02 \\
\hline $\mathrm{C}_{3}$ & 0.27 & 8.20 & 1 & 4.00 & 1.20 & 7.60 & 5.60 & 1.00 & 1.00 & 2.20 & 2.60 & 2.04 & 0.12 \\
\hline $\mathrm{C}_{4}$ & 0.12 & 3.87 & 0.34 & 1 & 0.47 & 4.40 & 4.12 & 0.39 & 0.37 & 0.52 & 0.82 & 0.80 & 0.05 \\
\hline $\mathrm{C}_{5}$ & 0.25 & 8.00 & 0.90 & 3.60 & 1 & 6.60 & 5.40 & 0.90 & 1.10 & 1.60 & 2.40 & 1.85 & 0.11 \\
\hline $\mathrm{C}_{6}$ & 0.11 & 1.84 & 0.16 & 0.29 & 0.21 & 1 & 2.94 & 0.17 & 0.17 & 0.32 & 0.24 & 0.36 & 0.02 \\
\hline $\mathrm{C}_{7}$ & 0.13 & 2.73 & 0.28 & 2.34 & 0.28 & 4.06 & 1 & 0.38 & 0.38 & 0.51 & 0.74 & 0.68 & 0.04 \\
\hline $\mathrm{C}_{8}$ & 0.25 & 7.80 & 1.00 & 3.60 & 1.20 & 6.80 & 5.20 & 1 & 1.00 & 1.20 & 2.40 & 1.85 & 0.11 \\
\hline $\mathrm{C}_{9}$ & 0.26 & 7.80 & 1.00 & 3.80 & 1.10 & 7.00 & 5.20 & 1.00 & 1 & 1.60 & 2.20 & 1.89 & 0.11 \\
\hline$C_{10}$ & 0.16 & 6.60 & 0.47 & 3.20 & 0.70 & 5.80 & 4.60 & 0.90 & 0.77 & 1 & 1.40 & 1.36 & 0.08 \\
\hline $\mathrm{C}_{11}$ & 0.12 & 5.00 & 0.40 & 2.60 & 0.52 & 5.60 & 4.30 & 0.43 & 0.47 & 0.80 & 1 & 1.02 & 0.06 \\
\hline Sum & 2.77 & 61.84 & 9.47 & 33.95 & 11.21 & 61.80 & 47.99 & 10.32 & 10.39 & 16.33 & 22.26 & 17.42 & 1.00 \\
\hline Sum*PV & 0.83 & 1.22 & 1.11 & 1.55 & 1.19 & 1.27 & 1.87 & 1.09 & 1.12 & 1.27 & 1.31 & & \\
\hline$\Lambda \max$ & \multicolumn{13}{|c|}{13.86} \\
\hline $\mathrm{Cl}$ & \multicolumn{13}{|c|}{0.286} \\
\hline CR & \multicolumn{13}{|c|}{0.189} \\
\hline
\end{tabular}

Table 11: AHP round 1 analysis - Weights of Criteria $\left(X_{i j}\right)$.

\begin{tabular}{|l|l|}
\hline $\mathbf{N}$ & $\mathbf{R}$ \\
\hline 3 & 0.58 \\
\hline 4 & 0.90 \\
\hline 5 & 1.12 \\
\hline 6 & 1.24 \\
\hline 7 & 1.32 \\
\hline 10 & 1.41 \\
\hline 11 & 1.45 \\
\hline
\end{tabular}

Table 12: Random index (RI).

\begin{tabular}{|c|c|c|c|c|c|c|c|c|c|c|c|c|c|}
\hline Criteria & $C_{1}$ & $\mathrm{C}_{2}$ & $\mathrm{C}_{3}$ & $\mathrm{C}_{4}$ & $\mathrm{C}_{5}$ & $\mathrm{C}_{6}$ & $\mathrm{C}_{7}$ & $\mathrm{C}_{8}$ & $\mathrm{C}_{9}$ & $C_{10}$ & $C_{11}$ & 11th root & PV \\
\hline $\mathrm{C}_{1}$ & 1.00 & 4.00 & 3.00 & 1.00 & 1.00 & 1.00 & 1.00 & 3.00 & 1.00 & 2.00 & 2.00 & 1.57 & 0.13 \\
\hline $\mathrm{C}_{2}$ & 0.25 & 1.00 & 1.00 & 0.25 & 0.25 & 0.33 & 0.20 & 1.00 & 0.33 & 0.50 & 0.50 & 0.43 & 0.03 \\
\hline $\mathrm{C}_{3}$ & 0.33 & 1.00 & 1.00 & 0.33 & 0.33 & 0.50 & 0.33 & 1.00 & 0.50 & 1.00 & 1.00 & 0.59 & 0.05 \\
\hline $\mathrm{C}_{4}$ & 1.00 & 4.00 & 3.00 & 1.00 & 1.00 & 1.00 & 1.00 & 3.00 & 1.00 & 2.00 & 2.00 & 1.57 & 0.13 \\
\hline $\mathrm{C}_{5}$ & 1.00 & 4.00 & 3.00 & 1.00 & 1.00 & 2.00 & 1.00 & 3.00 & 1.00 & 2.00 & 2.00 & 1.67 & 0.14 \\
\hline $\mathrm{C}_{6}$ & 1.00 & 3.00 & 2.00 & 1.00 & 0.50 & 1.00 & 0.50 & 2.00 & 1.00 & 1.00 & 1.00 & 1.11 & 0.09 \\
\hline$C_{7}$ & 1.00 & 5.00 & 3.00 & 1.00 & 1.00 & 2.00 & 1.00 & 4.00 & 1.00 & 2.00 & 2.00 & 1.75 & 0.14 \\
\hline $\mathrm{C}_{8}$ & 0.33 & 1.00 & 1.00 & 0.33 & 0.33 & 0.50 & 0.25 & 1.00 & 0.50 & 0.50 & 1.00 & 0.54 & 0.04 \\
\hline $\mathrm{C}_{9}$ & 1.00 & 3.00 & 2.00 & 1.00 & 1.00 & 1.00 & 1.00 & 2.00 & 1.00 & 1.00 & 2.00 & 1.33 & 0.11 \\
\hline$C_{10}$ & 0.50 & 2.00 & 1.00 & 0.50 & 0.50 & 1.00 & 0.50 & 2.00 & 1.00 & 1.00 & 1.00 & 0.88 & 0.07 \\
\hline$C_{11}$ & 0.50 & 2.00 & 1.00 & 0.50 & 0.50 & 1.00 & 0.50 & 1.00 & 0.50 & 1.00 & 1.00 & 0.78 & 0.06 \\
\hline
\end{tabular}


Citation: Khalil MA, Suliman SMA (2017) Municipal Waste Landfill Site Selection Model for Bahrain. Int J Waste Resour 7: 312. doi: 10.4172/2252-

Page 10 of 11

\begin{tabular}{|c|c|c|c|c|c|c|c|c|c|c|c|c|c|}
\hline Sum & 7.91 & 30.00 & 21.00 & 7.91 & 7.41 & 11.33 & 7.28 & 23.00 & 8.83 & 14.00 & 15.50 & 12.22 & 1.00 \\
\hline Sum*PV & 1.02 & 1.05 & 1.01 & 1.02 & 1.01 & 1.02 & 1.04 & 1.01 & 0.96 & 1.01 & 0.99 & & \\
\hline$\Lambda \max$ & \multicolumn{13}{|c|}{11.15} \\
\hline $\mathrm{Cl}$ & \multicolumn{13}{|c|}{0.015} \\
\hline CR & \multicolumn{13}{|c|}{0.010} \\
\hline
\end{tabular}

Table 13: AHP round 2 analysis - Weights of Criteria $\left(X_{i j}\right)$.

\begin{tabular}{|c|c|c|c|c|c|}
\hline \multicolumn{6}{|c|}{ C2: Distance from residential areas } \\
\hline Sites & L1 & L2 & L3 & L4 & L5 \\
\hline L1 & 1.00 & 0.35 & 0.57 & 0.73 & 1.19 \\
\hline L2 & 2.86 & 1.00 & 1.64 & 2.09 & 3.40 \\
\hline L3 & 1.75 & 0.61 & 1.00 & 1.27 & 2.07 \\
\hline L4 & 1.37 & 0.48 & 0.79 & 1.00 & 1.63 \\
\hline L5 & 0.84 & 0.29 & 0.48 & 0.61 & 1.00 \\
\hline \multicolumn{6}{|c|}{ C3: Distance from agricultural land } \\
\hline Sites & L1 & L2 & L3 & L4 & $\mathbf{L 5}$ \\
\hline L1 & 1.00 & 0.99 & 0.83 & 0.93 & 0.95 \\
\hline L2 & 1.01 & 1.00 & 0.84 & 0.94 & 0.96 \\
\hline L3 & 1.20 & 1.19 & 1.00 & 1.12 & 1.14 \\
\hline L4 & 1.08 & 1.07 & 0.90 & 1.00 & 1.03 \\
\hline L5 & 1.05 & 1.04 & 0.87 & 0.98 & 1.00 \\
\hline
\end{tabular}

Table 14: AHP - Relative ratings (ratios) for each decision alternatives.

\begin{tabular}{|c|c|c|c|c|c|c|c|}
\hline \multicolumn{8}{|c|}{ C2: Distance from residential areas } \\
\hline Sites & L1 & L2 & L3 & L4 & L5 & 5th root & PV \\
\hline L1 & 1.00 & 0.33 & 0.50 & 1.00 & 1.00 & 0.70 & 0.13 \\
\hline L2 & 3.00 & 1.00 & 2.00 & 2.00 & 3.00 & 2.05 & 0.37 \\
\hline L3 & 2.00 & 0.50 & 1.00 & 1.00 & 2.00 & 1.15 & 0.21 \\
\hline L4 & 1.00 & 0.50 & 1.00 & 1.00 & 2.00 & 1.00 & 0.18 \\
\hline L5 & 1.00 & 0.33 & 0.50 & 0.50 & 1.00 & 0.61 & 0.11 \\
\hline Sum & 8.00 & 2.66 & 5.00 & 5.50 & 9.00 & 5.50 & 1.00 \\
\hline Sum*PV & 1.01 & 0.99 & 1.04 & 1.00 & 0.99 & & \\
\hline$\lambda \max$ & \multicolumn{7}{|c|}{5.04} \\
\hline $\mathrm{Cl}$ & \multicolumn{7}{|c|}{0.01} \\
\hline CR & \multicolumn{7}{|c|}{0.01} \\
\hline
\end{tabular}

Table 15: AHP - judgment matrix for each decision alternative.

\begin{tabular}{|c|c|c|c|c|c|c|c|c|c|c|c|c|c|c|}
\hline \multirow{2}{*}{\multicolumn{2}{|c|}{$\begin{array}{l}\text { Criteria } \\
\text { Weight }\end{array}$}} & C1 & \multirow{3}{*}{$\begin{array}{c}\text { C2 } \\
\mathbf{0 . 0 3} \\
0.13\end{array}$} & \multirow{3}{*}{\begin{tabular}{c|} 
C3 \\
$\mathbf{0 . 0 5}$ \\
0.20
\end{tabular}} & \multirow{3}{*}{\begin{tabular}{|c|} 
C4 \\
0.13 \\
0.03
\end{tabular}} & \multirow{3}{*}{\begin{tabular}{|c|} 
C5 \\
0.14 \\
0.23
\end{tabular}} & \multirow{3}{*}{\begin{tabular}{c|} 
C6 \\
0.09 \\
0.03
\end{tabular}} & \multirow{3}{*}{\begin{tabular}{|c|} 
C7 \\
0.14 \\
0.38
\end{tabular}} & \multirow{3}{*}{\begin{tabular}{|c|} 
C8 \\
0.04 \\
0.20
\end{tabular}} & \multirow{3}{*}{\begin{tabular}{c|} 
C9 \\
0.11 \\
0.17
\end{tabular}} & \multirow{3}{*}{$\begin{array}{l}\text { C10 } \\
0.07 \\
0.20\end{array}$} & \multirow{3}{*}{$\begin{array}{l}\text { C11 } \\
0.06 \\
0.17\end{array}$} & \multirow{3}{*}{$\begin{array}{c}\text { Average } \\
\text { Weight }\end{array}$} & \multirow{3}{*}{$\begin{array}{c}\text { Ranking } \\
5\end{array}$} \\
\hline & & \multirow{2}{*}{$\begin{array}{l}\mathbf{0 . 1 3} \\
0.20\end{array}$} & & & & & & & & & & & & \\
\hline \multirow{5}{*}{ 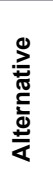 } & L1 & & & & & & & & & & & & & \\
\hline & L2 & 0.20 & 0.37 & 0.20 & 0.16 & 0.23 & 0.05 & 0.35 & 0.20 & 0.20 & 0.20 & 0.15 & 0.208 & 2 \\
\hline & L3 & 0.20 & 0.21 & 0.20 & 0.27 & 0.20 & 0.24 & 0.20 & 0.20 & 0.20 & 0.23 & 0.20 & 0.214 & 1 \\
\hline & L4 & 0.20 & 0.18 & 0.20 & 0.27 & 0.20 & 0.26 & 0.04 & 0.20 & 0.20 & 0.23 & 0.23 & 0.195 & 4 \\
\hline & L5 & 0.20 & 0.11 & 0.20 & 0.27 & 0.15 & 0.43 & 0.03 & 0.20 & 0.23 & 0.15 & 0.26 & 0.199 & 3 \\
\hline
\end{tabular}

Table 16: AHP weighted average rating for each decision alternative.

\begin{tabular}{|c|c|c|c|}
\hline \multirow{2}{*}{ AlternativeSite } & \multicolumn{2}{|c|}{ FMHP } & \multicolumn{2}{c|}{ AHP } \\
\cline { 2 - 4 } & Average Weight & Ranking & Average Weight \\
\hline Landfill (1) & 0.11791 & 5 & 0.184 \\
\hline Landfill (2) & 0.12542 & 2 & 0.208 \\
\hline Landfill (3) & 0.13137 & 1 & 0.214 \\
\hline Landfill (4) & 0.12541 & 3 & 0.195 \\
\hline
\end{tabular}

Table 17: Comparison of results. 
Citation: Khalil MA, Suliman SMA (2017) Municipal Waste Landfill Site Selection Model for Bahrain. Int J Waste Resour 7: 312. doi: 10.4172/22525211.1000312

environmental hazards. As though, landfill (2) and (3) are the most preferable alternatives with higher preference to landfill (3) as it is the first ranked by both approaches.

Back to Figure 2, landfill (3) is in the middle of the blue zone (Proposed area) and just below the existing landfill. Landfill (2) is adjacent to the existing landfill and has a nonhomogeneous shape due to some buildings belonging to Bramco staff just next to this landfill proposed area. Adding to that, the proposed area for landfill (3) is bigger than landfill (2) their areas are $1.95 \mathrm{~km}^{2}$ and $1.82 \mathrm{~km}^{2}$, rtalternative.

\section{References}

1. O'Donovan J (2013) Askar Landfill Risk Assessment, Project no. 8298.

2. Melo André LO, Calijuri Maria Lúcia, Duarte Izabel CD, Azevedo Roberto F, Lorentz Juliana F (2006) Strategic Decision Analysis for Selection of Landfill Sites. Journal of Surveying Engineering, pp: 83-92.

3. Charusiri P, Ladachart R (2008) GIS Application for the Determination of Geological Barriers: A Case Study of Landfill Site Selection in Songkhia Province, Thailand. International Journal of Geoinformatics.

4. Tinc-Yu C (2013) Data Construction Process and Qualiflex-Based Method for Multiple-Criteria Group Decision Making With Interval-Valued Intuitionistic Fuzzy Sets. International Journal of Information Technology \& Decision Making 12: $425-467$

5. Yakubah B, Rodney T (2011) Landfill Site Selection by Integrating Geographical Information Systems and Multi-Criteria Decision Analysis: A Case Study of Freetown, Sierra Leone. African Geographical Review 1: 67-99.
6. Yesilnacar MI, Suzen ML, Kaya BS, Doyuran V (2012) Municipal solid waste landfill site selection for the city of Sanliurfa-Turkey: An example using MCDA integrated with GIS. International Journal of Digital Earth 5: 147-164.

7. Agaji I, Wajiga GM (2012) An Object Oriented System for the Location of Landfills for Nigerian Municipals. Science World Journal.

8. Harun H, Haris H (2014) A Multi-Criteria Approach to Selecting a Landfill Site with the Aim of Protecting the Environment. Pol J Environ Stud 23: 1499-1505.

9. Ahmad SS, Ahmad WM (2014) Geospatial Based Approach for Enhancing Environment Sustainability of Srinagar city - A Study on Solid Waste Disposal 7: 289-302.

10. Keivan G, Javad L (2014) Waste Disposal Site Selection Using an Analytic Hierarchal Pairwise Comparison and ELECTRE Approaches Under Fuzzy Environment. Journal of Intelligent and Fuzzy Systems 26: 693-704.

11. No Authors Listed (2016) National Detail Land Use Map 2030. Official Gazette no. 3262, Information Affairs, Kingdom of Bahrain.

12. Zadeh LA, Klaua D (1965) Fuzzy set. Wikipedia

13. Saaty Thomas L (1990) How to Make a Decision: The Analytic Hierarchy Process. European Journal of Operational Research 48: 9-26.

14. Central Informatics Organisation (2011) Population and Population Density by Governorates. Central Informatics Organisation, Kingdom of Bahrain

15. Environmental Health Directorate (1988) Review of Waste Disposal Operations at Askar Landfill Site. Central Municipal Council, State of Bahrain.

16. Gazette (2016) Kingdom of Bahrain National Detail Land Use Map 2030

17. Technical Services Directorate (1993) Site Investigation Report for Askar Landfill (Factual), Power and Water Public Works Affairs, Ministry of Works, State of Bahrain. 